УДК 338.43:633.18

https://doi.org/10.35546/kntu2078-4481.2021.2.25

P.B. MOPO3OB

Херсонський державний аграрно-економічний університет

ORCID: 0000-0002-1454-6296

\title{
ПРОГНОЗУВАННЯ КОМПЛЕКСНОГО РОЗВИТКУ ГАЛУЗІ РИСІВНИЦТВА
}

У статті розглядаються теоретичні засади організаиії прогнозування комплексного розвитку галузі рисівництва в Украӥні. У процесі дослідження доведено, щзо прогноз як передбачення на основі наявних даних напряму, характеру й особливостей комплексного розвитку галузі рисівництва є засобом обтрунтування вибору тієї чи іншої стратегї та прийняття конкретних рімень відповідними органами законодавчої та виконавчої влади, органами місчевого самоврядування щуодо регулювання економічних, екологічних і сочіальних процесів на галузевому рівні. У контексті даного дослідження $\epsilon$ підстави вважати, щь прогнозування розвитку агропромислового виробництва на галузевому рівні-науково обтрунтоване передбачення напрямів розвитку окремої сільськогосподарської галузі, можливого стану галузі в майбутньому, а також альтернативних шляхів і строків досягнення параметрів економічного $i$ соціального розвитку цієї галузі економіки. Доведено, щуо головними завданнями прогнозування розвитку галузі рисівництва є виявлення і аналіз можливих варіантів розвитку соціальних і еколого-економічних процесів у рисівництві, оцінка розвитку зазначених процесів у майбутньому, передбачення проблем, пов'язаних із розвитком иієї галузі. Досягнення прогнозно-індикативних показників розвитку галузі рисівництва повинно забезпечуватися за умов раціонального використання зрошувальної води, земельних, природних та інших наявних ресурсів $і$ територіальних переваг зони рисосіяння для збільшення посівних площ та обсягів виробнищтва зерна рису; підвищення конкурентоспроможності продукиії вітчизняного рисівництва на внутрішньому та зовнішньому ринках $і$ трудової зайнятості сільського населення; поглиблення спеціалізащії, концентращії й інтегращії виробництва.

Ключові слова: прогнозування, прогноз, управління, рисівниџтво, розвиток.

P.B. MOPO3ОB

Херсонский государственный аграрно-экономический университет

ORCID: 0000-0002-1454-6296

\section{ПРОГНОЗИРОВАНИЕ КОМПЛЕКСНОГО РАЗВИТИЯ ОТРАСЛИ РИСОВОДСТВА}

В статье рассматриваются теоретические основы организаџии прогнозирования комплексного развития отрасли рисоводства в Украине. В проиессе исследования доказано, что прогноз как предвидение на основе имеюшихся данных направления, характера и особенностей комплексного развития отрасли рисоводства является средством обоснования выбора той или иной стратегии и принятия конкретных решений соответствующими органами законодательной и исполнительной власти, органами местного самоуправления относительно регулирования экономических, экологических и социальных процессов на отраслевом уровне. В контексте данного исследования можно полагать, что прогнозирование развития агропромышленного производства на отраслевом уровне-научно обоснованное предвидение направлений развития отдельной сельскохозяйственной отрасли, возможного состояния отрасли в будущем, а также альтернативных путей и сроков достижения параметров экономического и социального развития этой отрасли экономики. Доказано, что основными задачами прогнозирования развития отрасли рисоводства является выявление и анализ возможных вариантов развития сочиальных и эколого-экономических процессов в рисоводстве, оченка развития указанных процессов в будущеем, предвидение проблем, связанных с развитием этой отрасли. Достижение прогнозно-индикативных показателей развития отрасли рисоводства должно обеспечиваться в условиях раџионального использования оросительной воды, земельных, природньх и других имеющихся ресурсов и территориальных преимуществ зоны рисоводства для увеличения посевных площадей и объемов производства зерна риса; повышения конкурентоспособности продукции отечественного рисоводства на внутреннем и внешнем рынках и трудовой занятости сельского населения; углубления специализаџии, концентраџчи и интеграции производства.

Ключевые слова: прогнозирование, прогноз, управление, рисоводство, развитие.

R.V. MOROZOV

Kherson State agrarian and economic University ORCID: 0000-0002-1454-6296 


\section{FORECASTING THE COMPLEX DEVELOPMENT OF THE RICE INDUSTRY}

The article considers the theoretical foundations of the organization of forecasting the complex development of the rice industry in Ukraine. In the process of research it is proved that the forecast as a prediction on the basis of available data of the direction, nature and features of complex development of the rice industry is a means of justifying the choice of a strategy and making specific decisions by relevant legislative and executive bodies, local governments to regulate economic, environmental and social processes at the sectoral level. In the context of this study, there is reason to believe that forecasting the development of agroindustrial production at the sectoral level - a scientifically sound prediction of the development of a particular agricultural sector, the possible state of the industry in the future, and alternative ways and timing of economic and social development. It is proved that the main tasks of forecasting the development of the rice industry are to identify and analyze possible options for the development of social and environmental and economic processes in rice, assess the development of these processes in the future, anticipate problems associated with the development of this industry. Achieving forecast-indicative indicators of rice industry development should be ensured under conditions of rational use of irrigation water, land, natural and other available resources and territorial advantages of rice sowing zone to increase sown areas and rice grain production; increasing the competitiveness of domestic rice products in domestic and foreign markets and employment of the rural population; deepening of specialization, concentration and integration of production.

Key words: forecasting, forecast, management, drawing, development.

\section{Постановка проблеми}

За нинішньої економічної ситуації розвиток галузі рисівництва потребує поліпшення організаційно-управлінського забезпечення. 3 огляду на це запровадження управлінської системи, яка б забезпечувала комплексний підхід до розв'язання існуючих галузевих проблем слід розглядати як фундаментальну проблему, що потребує більш грунтовного розкриття у теоретичному, методологічному та організаційному плані, вирішення якої сприятиме ефективному функціонуванню галузі рисівництва в Україні.

\section{Аналіз останніх досліджень і публікацій}

Теоретичним та прикладним аспектам прогнозування присвячені наукові праці багатьох вітчизняних та закордонних учених: Л.Ю. Басовського [1], В.Г. Воронкової [5], В.М. Геєця [10] та інших. Важливу роль у дослідженні проблем організації, прогнозування та планування агропромислового комплексу відіграли праці П.С. Березівського [2] та Н.І. Михалюк [2]. Водночас, незважаючи на вагомість даної проблематики й посилену увагу до неї багатьох провідних дослідників, окремі іiі аспекти залишаються недостатньо вивченими. Актуальність теми зумовлена необхідністю розроблення теоретичних засад організації прогнозування комплексного розвитку галузі рисівництва в Україні.

\section{Формулювання мети дослідження}

Метою дослідження є розробка теоретичних засад та обгрунтування практичних рекомендацій щодо організації прогнозування комплексного розвитку галузі рисівництва в Україні.

\section{Виклад основного матеріалу дослідження}

Сучасне тлумачення поняття «прогнозування» має багато визначень. Сутність прогнозування вітчизняні науковці визначають як «...процес наукового передбачення, визначення тенденцій розвитку й образу майбутнього...» [4, с. 362], «...наукове обгрунтування можливих змін або якісного стану економіки в майбутньому, а також альтернативних шляхів і строків досягнення цього стану» [11, с. 29], «...метод планування, в якому передбачення майбутнього спирається на набутий досвід та поточні припущення відносно майбутнього ...» [12, с. 411], «...сукупність засобів і заходів мислення, що дають змогу на основі аналізу ретроспективних, екзогенних (зовнішніх) та ендогенних (внутрішніх) даних, а також їх змін у певному періоді часу вивести судження певної достовірності стосовно майбутнього розвитку об'єкта» [8, с. 342].

Головними задачами прогнозування є: науковий аналіз соціально-економічних і науковотехнічних процесів; оцінка розвитку зазначених процесів в майбутньому; передбачення нових проблем, пов'язаних з цим розвитком; виявлення й аналіз можливих варіантів розвитку соціальних, економічних, науково-технічних процесів.

Прогноз як передбачення на основі наявних даних напряму, характеру й особливостей комплексного розвитку галузі рисівництва $є$ засобом обгрунтування вибору тієї чи іншої стратегії та прийняття конкретних рішень відповідними органами законодавчої та виконавчої влади, органами місцевого самоврядування щодо регулювання економічних, екологічних і соціальних процесів на галузевому рівні (рис. 1). 


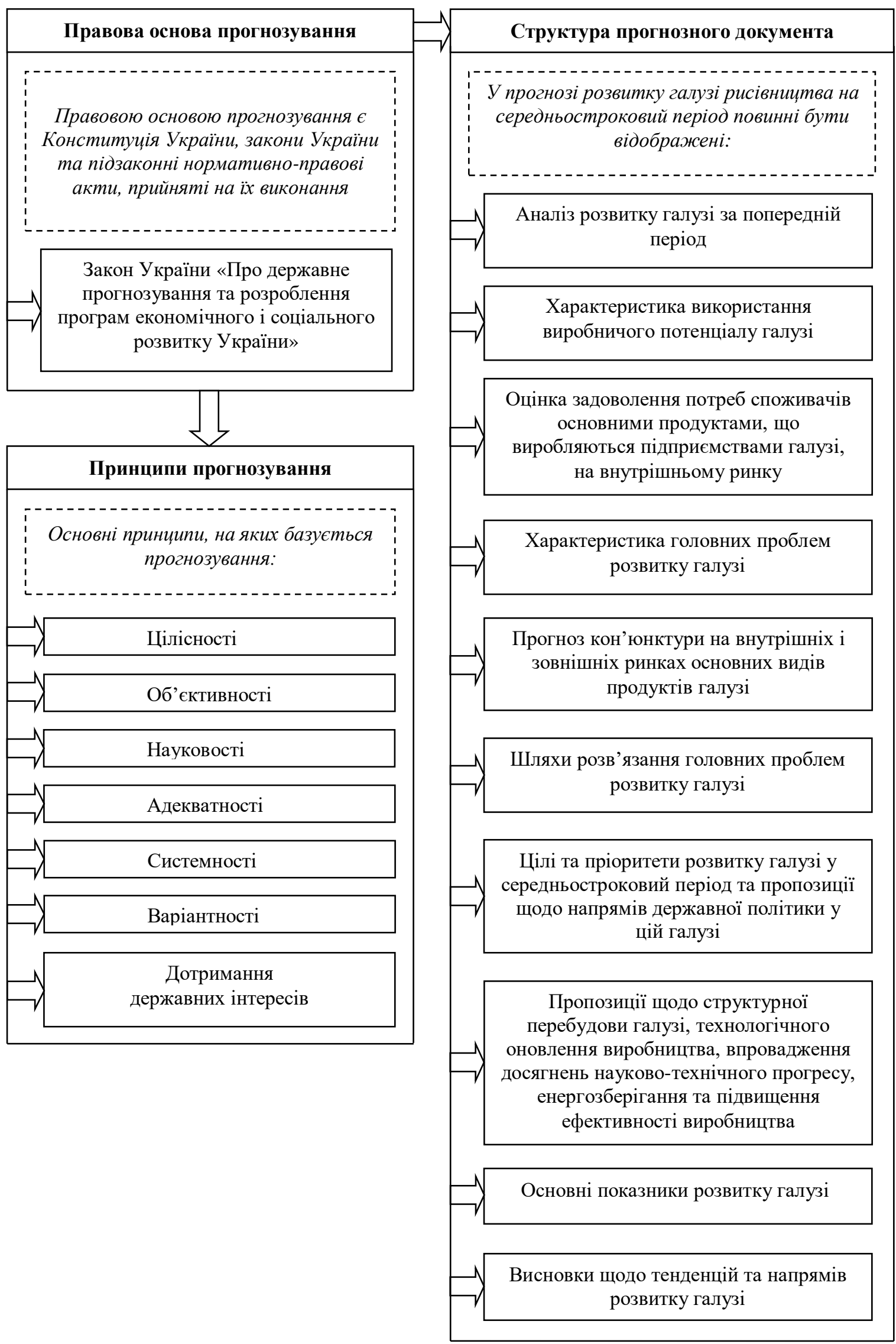

Рис. 1. Структура прогнозного документа щодо розвитку галузі рисівництва 
У прогнозі розвитку галузі рисівництва на середньостроковий період повинні бути відображені: аналіз розвитку галузі за попередній період; характеристика використання виробничого потенціалу галузі; оцінка задоволення потреб споживачів основними продуктами, що виробляються підприємствами галузі, на внутрішньому ринку; характеристика головних проблем розвитку галузі; прогноз кон'юнктури на внутрішніх і зовнішніх ринках основних видів продуктів галузі; шляхи розв'язання головних проблем розвитку галузі; цілі та пріоритети розвитку галузі у середньостроковий період та пропозиції щодо напрямів державної політики у цій галузі; пропозиції щодо структурної перебудови галузі, технологічного оновлення виробництва, впровадження досягнень науково-технічного прогресу, енергозберігання та підвищення ефективності виробництва; основні показники розвитку галузі; висновки щодо тенденцій та напрямів розвитку галузі.

Основні принципи, на яких базується прогнозування, такі: цілісності; об’єктивності; науковості; адекватності; системності; варіантності; дотримання державних інтересів.

Щоб досягти бажаних результатів, прогнозні документи розвитку галузі рисівництва доцільно розробляти на основі комплексного аналізу стану використання природного, виробничого, науковотехнічного та трудового потенціалу, ii конкурентоспроможності та оцінки досягнутого рівня економічного розвитку з урахуванням впливу зовнішніх політичних, економічних та інших факторів $\mathrm{i}$ очікуваних тенденцій зміни впливу цих факторів у перспективі. Показники прогнозних документів $\epsilon$ орієнтиром для розробки рисосійними господарствами власних прогнозів, бізнес-планів та інших документів.

Результати прогнозів ураховуються при розробці програм розвитку галузей економіки, що розробляються 3 метою реалізації державної політики щодо регулювання розвитку цих галузей, концентрації фінансових, матеріально-технічних та інших ресурсів, виробничого і науково-технічного потенціалу, а також координації діяльності центральних і місцевих органів виконавчої влади та органів місцевого самоврядування, підприємств, установ, організацій і громадян для розв'язання найважливіших галузевих проблем.

Слід зауважити, що успішне виконання прогнозних досліджень залежить від рівня володіння методами і способами прогнозування. Як зазначає В.М. Нелеп, «якість прогнозів значною мірою залежить від методів прогнозування...» [11, с. 31].

За умов інтенсивного зростання обсягів наукової i науково-технічної інформації, швидкозмінності й оновлення системи наукових знань відбувається пошук досконаліших методів прогнозування. Зокрема, у наукових працях В.П. Боровікова та інших [3] розглядаються практичні методи прогнозування в системі STATISTICA (система статистичної обробки даних) разом 3 викладенням необхідних теоретичних основ (викладені основні ідеї, методи і результати теорії стохастичного прогнозування). Е.О. Вуколов [6] досліджує різні методи статистичного аналізу: непараметричні методи математичної статистики, однофакторний дисперсійний аналіз, регресійний аналіз, найпростіші методи аналізу часових рядів, кластерний аналіз. В цих книгах наведені необхідні теоретичні відомості та розглядається рішення завдань прикладної статистики з використанням пакету STATISTICA.

Нині в економічних дослідженнях велике значення має теорія і практика економетричного моделювання, яка дозволяє дослідити і кількісно визначити внутрішні і зовнішні зв'язки між показниками економічних систем, вивчати закономірності їх формування і тенденції розвитку.

Економетрія визначається як напрям в економіці, заснований на застосуванні математичних моделей для аналізу і прогнозування економічних явищ і пов'язане з визначенням і оцінкою адекватності реальних явищ математичним зображенням. Як відмічають П.С. Березівський і Н.І. Михалюк, «під час формування системи моделей необхідно враховувати великий обсяг початкової інформації. Її отримання вимагає своїх спеціальних методів дослідження в різних областях науки...» [2, с. 358].

Прогнозування еколого-економічного і соціального розвитку галузі рисівництва доцільно здійснювати методом екстраполяції та іншими методами прогнозування за індикаторами (індивідуальними та зведеними індексами, що характеризують динаміку відповідних явищ, зокрема економічних, у галузі рисівництва у часі).

Вважаємо, що про стабільний зрівноважений розвиток галузі рисівництва буде свідчити однорідність розрахованих індикаторів (див. формули 1-4), за умов, що аналізується неоднорідний (різний за змістом, одиницями виміру) масив даних різновекторної спрямованості. Крім того, на нашу думку, такий підхід дозволяє відбити значущість кожного із врахованих компонентів соціальноекономічної й екологічної складової у виконанні цільової функції, оскільки зміна кожного із окремих індикаторів призводить до зміни значення узагальнюючого показника.

Враховуючи вищенаведене, можна стверджувати, що для визначення кількісного впливу основних показників (індикаторів) розвитку галузі рисівництва на інтегральний індекс доцільно застосувати багатофакторне кореляційно-регресійне моделювання. 
Початковим пунктом будь-якого регресійного аналізу є наступна ситуація: об'єкт дослідження представлений спостережними величинами (змінними) $y, x_{1}, \ldots, x_{n}$. Між цими величинами існує об'єктивний зв'язок. На основі знань об'єкта досліджень точно відомо, що спостережена величина $у$ залежить від спостережених величин $x_{1}, \ldots, x_{n}$. Цей зв'язок між залежною величиною $y$ і незалежними змінними $x_{1}, \ldots, x_{n}$ принципово можна зобразити лінійною функцією [7, с. 21].

Проте в дійсності спостережені величини відхиляються від цього функціонального зв'язку. Ці відхилення включаються в модель, при цьому припускається, що лінійний функціональний зв'язок між величинами $y, x_{1}, \ldots, x_{n}$ доповнюється адитивною випадковою змінною $u$. Таким чином, лінійне регресійне рівняння функціональних зв'язків можна описати формулою:

$$
y=u+a_{1} x_{1}+\ldots+a_{n} x_{n}
$$

де $y, x_{1}, \ldots, x_{n}$-спостережені величини; $a_{1}, \ldots, a_{n}$-коефіцієнти регресії; $u$-адитивна випадкова змінна.

Значення спостережених величин $y, x_{1}, \ldots, x_{n}$ вважаються при оцінці параметрів наперед заданими. Це означає, що по кожній з цих величин необхідно мати ряд даних. Значення випадкової змінної $u$ та істинне значення кожного параметра $a_{1}, \ldots, a_{n}$ в конкретному випадку невідомі.

Якщо регресійне рівняння описує об'єкт дослідження 3 економічної сфери і обгрунтовано в теоретично-економічному відношенні, то йдеться про економетричне рівняння. Регресійна модель перетворюється в економетричну перш за все шляхом ії̈ теоретично-економічного обгрунтування.

Обгрунтований таким чином регресійний аналіз перетворюється в економетричний аналіз. Відповідно можна стверджувати, що залежно від теорії, яка застосовується при побудові регресійного рівняння, йдеться про різні рівняння, моделі, аналіз тощо.

За результатами регресійного аналізу можна визначити залежність змодельованого інтегрального індексу від індикаторів, що характеризують соціально-економічний галузевий розвиток 3 урахуванням екологічної складової.

Разом із тим, необхідно також здійснити перевірку регресійної моделі на адекватність реальному досліджуваному процесу. Техніко-економічне обгрунтування індикаторів, що розраховуються 3 використанням регресійного аналізу, повинно враховувати наступні параметри показників (спостережних величин): коефіцієнт кореляції $(R)$; коефіцієнт детермінації $\left(R^{2}\right)$; коефіцієнт регресії $\left(a_{1}, \ldots, a_{n}\right)$; стандартна похибка $(\Delta) ; t$-критерій; $F$-критерій (Фішера).

Вибірковий коефіцієнт множинної детермінації (коефіцієнт детермінації) характеризує щільність зв'язку загального впливу всіх незалежних факторів $x_{1}, \ldots, x_{n}$ на залежну змінну $y$. Наведений коефіцієнт детермінації характеризує, якою мірою варіація залежної змінної визначається варіацією незалежних факторів. Чим ближчий він до одиниці, тим більша варіація залежної змінної визначається варіацією незалежних змінних. Тому $R^{2}$ показує, наскільки якісно побудована регресійна модель до значень $y$, які спостерігаються [9, с. 178].

Щодо множинного коефіцієнта кореляції $(R)$, то як відмічає О.А. Корольов, «...він характеризує щільність лінійного зв'язку усіх незалежних факторів $x_{1}, \ldots, x_{n}$ із залежною змінною $y$. Для нього 3 урахуванням та без урахування числа ступенів свободи характерна така сама зміна числового значення як і для коефіцієнта детермінації» [9, с. 179].

Обчислене значення $F$-критерію (Фішера) порівнюється з табличним при ступенях вільності $m$ i

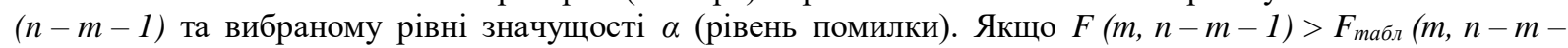
$1, \alpha)$, то гіпотезу про істинність зв'язку між залежною і незалежними змінними моделі приймаємо, інакше - відкидаємо [9, с. 186].

I нарешті, розглянемо питання, яке пов'язане зі значущістю коефіцієнта кореляції. Оскільки коефіцієнт кореляції є також вибірковою характеристикою, яка може відхилятись від свого «істинного» значення, значущість коефіцієнта кореляції також потребує перевірки. Вона базується на $t$-критерії.

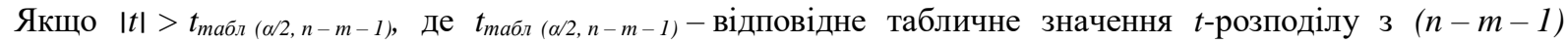
ступенями вільності, то можна зробити висновок про значущість коефіцієнта кореляції між залежною і незалежними змінними моделі [9, с. 188]. Таким чином здійснюється перевірка регресійної моделі на адекватність реальному досліджуваному процесу.

Такий підхід наближає нас до розуміння головної мети регресійного аналізу, зокрема, не можна не погодитися із Й. Грубером в тому, що «...мета регресійного аналізу-отримання теоретично обгрунтованого і статистично надійного точкового та інтервального прогнозів залежної величини у...» [7, с. 21].

3 огляду на викладений підхід та узагальнюючи зарубіжний і вітчизняний практичний досвід й наукові дослідження, виділимо серед методів прогнозування методи екстраполяції (тренда), тобто продовження в майбутньому тенденцій, що склалися у минулому. Лінія тренду широко застосовується для розв'язання задач прогнозування за допомогою методів регресійного аналізу. Тренд являє собою 
узагальнений вираз дій комплексу факторів, тобто він є їхньою рівнодіючою. На відміну від рівняння множинної регресії, самі чинники тут не показуються і вплив кожного з них не виділяється. За єдиний чинник береться момент часу. Рівняння часового ряду даних за лінійним законом має наступний вигляд:

$$
y=a_{0}+a_{1} t
$$

де $a_{0}$ - константа (початковий рівень тренда в момент або за період, що береться за початок відліку часу); $a_{1}-$ коефіцієнт регресії, що визначає швидкість і напрям розвитку досліджуваного показника; $t$ - порядковий номер індексу.

Слід також відмітити, що нині в теорії і практиці виконання прогнозних досліджень широко використовуються сучасні методи прогнозування часових рядів, зокрема, йдеться про метод двопараметричного експоненціального згладжування (метод Хольта і Брауна). Метод двопараметричного експоненціального згладжування складається з системи рівнянь, які можна описати формулою:

$$
\left\{\begin{array}{l}
\Omega_{t}=\alpha Y_{t}+(1-\alpha)\left(\Omega_{t-1}-T_{t-1}\right), \\
T_{t}=\beta\left(\Omega_{t}-\Omega_{t-1}\right)+(1-\beta) T_{t-1}, \\
\hat{Y}_{t+p}=\Omega_{t}+p T_{t}
\end{array},\right.
$$

Перше рівняння описує згладжений ряд загального рівня. За допомогою другого рівняння оцінюється тренд. Третє рівняння визначає прогноз на $p$ відліків часу вперед.

Значення $a$ і $\beta$ знаходиться в діапазоні від 0 до 1, але найчастіше їхнє значення вибирається 3 більш вузького діапазону $(0,25<a, \beta<0,5)$ і при цьому значення констант не обов'язково повинні співпадати. За нижчих значеннях $a$ більшою мірою враховуються попередні, ніж поточні, значення ряду і тенденція розвитку процесу; аналогічно нижчі значення $\beta$ переоцінюють минулий рух процесу порівняно 3 сучасним.

Розраховані прогнозні показники, що визначають тенденцій розвитку рисівництва у майбутньому, доцільно використовувати у стратегічному плануванні комплексного розвитку галузі рисівництва, спираючись на набутий досвід.

Разом $з$ тим, підкреслимо, що значна частина інформації повинна готуватися в окремих науководослідних інститутах та регіональних центрах наукового забезпечення агропромислового виробництва. Крім того, на науково-дослідні установи необхідно покласти найбільш загальні функції прогнозування перспектив розвитку зернового господарства відповідно до концепції сталого розвитку держави, діючих державних та регіональних програм, схем комплексного використання та охорони навколишнього середовища.

Одним 3 основних чинників, що забезпечують підвищення врожайності, відповідно і валові збори сільськогосподарських культур, $є$ використання нових високопродуктивних сортів. Для забезпечення насінням високих репродукцій рисосійних господарств України на території рисосіяння створені насіннєві господарства, які за ліцензійними угодами з Інститутом рису Національної академії аграрних наук України здійснюють вирощування насіння першої репродукції нових сортів.

Реалізація стратегічних цілей в частині розробки, удосконалення та впровадження зональних ресурсозберігаючих, екологічно безпечних технологій вирощування нових високоврожайних та адаптованих сортів, що допоможуть повною мірою реалізувати генетичний потенціал сортів, дозволить суттєво збільшити валове виробництво зерна рису. Для повноти реалізації потенціалу сортів рослини рису повинні бути забезпечені поживними речовинами, водою, мати надійну систему захисту. Проте, найважливіший момент - це надійна робота рисових зрошувальних систем. Виконання програмних заходів з реконструкції та відновлення внутрішньогосподарської мережі рисових зрошувальних систем, проведення капітального планування чеків забезпечить не тільки роботу систем у проектному режимі, а й зменшить непродуктивні втрати води для зрошення як під час іiї подачі до рисових полів, так і під час вегетації рису.

Таким чином, є підстави вважати, що прогнозування розвитку агропромислового виробництва на галузевому рівні - науково обгрунтоване передбачення напрямів розвитку окремої сільськогосподарської галузі, можливого стану галузі в майбутньому, а також альтернативних шляхів і строків досягнення параметрів економічного і соціального розвитку цієї галузі економіки.

\section{Висновки}

Головними завданнями прогнозування розвитку галузі рисівництва $є$ виявлення i аналіз можливих варіантів розвитку соціальних і еколого-економічних процесів у рисівництві, оцінка розвитку зазначених процесів у майбутньому, передбачення проблем, пов'язаних із розвитком цієї галузі. Досягнення прогнозно-індикативних показників розвитку галузі рисівництва повинно забезпечуватися за умов раціонального використання зрошувальної води, земельних, природних та інших наявних ресурсів і територіальних переваг зони рисосіяння для збільшення посівних площ та обсягів виробництва зерна 
рису; підвищення конкурентоспроможності продукції вітчизняного рисівництва на внутрішньому та зовнішньому ринках і трудової зайнятості сільського населення; поглиблення спеціалізації, концентрації й інтеграції виробництва.

\section{Список використаної літератури}

1. Басовский Л. Е. Прогнозирование и планирование в условиях рынка : учеб. пособ. / Басовский Л. Е. М. : ИНФРА-М, 2008. 260 с.

2. Березівський П. С. Організація, прогнозування та планування агропромислового комплексу : навч. посіб. / П. С. Березівський, Н. І. Михалюк. - 2-ге вид., стереот. Львів : Магнолія Плюс, 2006. 443 с.

3. Боровиков В. П. Прогнозирование в системе STATISTICA в среде WINDOWS: основы теории и интенсивная практика на компьютере : учеб. для вузов / В. П. Боровиков, Г. И. Ивченко. - 2-е изд., перераб. и доп. М. : Финансы и статистика, 2006. 368 с.

4. Василенко В. О. Стратегічне управління : навч. посіб. / В. О. Василенко, Т. І. Ткаченко. К. : ЦУЛ, 2003. 396 с.

5. Воронкова В. Г. Соціально-економічне прогнозування: навч. посіб. для студ. вузів / Воронкова В. Г. К. : Професіонал, 2004. 284 с.

6. Вуколов Э. А. Основы статистического анализа. Практикум по статистическим методам и исследованию операций с использованием пакетов STATISTICA и EXCEL : уч. пособ. по специальности «Менеджмент организации» / Вуколов Э. А. - 2-е изд., испр. и доп. М. : ФОРУМ, 2010. 463 с.

7. Грубер Й. Економетрія : [у II т.] / Грубер Й. К. : Нічлава, 1998. Т. І. 384 с.

8. Клименко М. О. Основи та методологія наукових досліджень : навч. посіб. / Клименко М. О., Фещенко В. П., Вознюк Н. М. К. : Аграрна освіта, 2010. 351 с.

9. Корольов О. А. Економетрія : навч. посіб. / Корольов О. А. - 2-ге вид., випр. та скор. К. : Книга, 2005. 416 с.

10 Моделі і методи соціально-економічного прогнозування : підруч. для студ. вузів / [В. М. Геєць та ін.]. Х. : ІНЖЕК, 2005. 396 с.

11. Нелеп В. М. Планування на аграрному підприємстві: [підручник - 2-ге вид., перероб. та допов.] / Нелеп В. М. К. : КНЕУ, 2004. 495 с.

12. Організація управління аграрною економікою : монографія / [М. Ф. Кропивко, В. П. Немчук, В. В. Россоха та ін.] ; за ред. М. Ф. Кропивка. К. : ННЦ ІАЕ, 2008. 420 с.

\section{References}

1. Basovsky L.E. Prognozirovaniye i planirovaniye v usloviyakh rynka [Textbook] / Basovsky L.E. / 2008, M: INFRA p. 260.

2. Berezovsky P.S. Orhanizatsiya, prohnozuvannya ta planuvannya ahropromyslovoho kompleksu [Textbook 2nd ed] / P.S. Berezovsky, N.I. Mikhalyuk. / 2006, Lviv: Magnolia Plus, p. 443. (in Ukrainian)

3. Borovikov V.P. Prognozirovaniye v sisteme STATISTICA v srede WINDOWS: osnovy teorii i intensivnaya praktika na komp'yutere: [Textbook 2nd ed.] / 2006, Borovikov V.P., Ivchenko G.I. Reworked. and ext. M: Finance and Statistics, p. 368.

4. Vasilenko V.O. Stratehichne upravlinnya [Textbook] / 2003, Vasilenko V.O., Tkachenko T.I.. K.: TSUL, p. 396. (in Ukrainian)

5. Voronkova V.G. Sotsialno-ekonomichne prohnozuvannya [Textbook] / Voronkova V.G. / 2004, K: Professionalws. p. 284. (in Ukrainian)

6. Vukolov E.A. Osnovy statisticheskogo analiza. Praktikum po statisticheskim metodam i issledovaniyu operatsiy s ispol'zovaniyem paketov STATISTICA i EXCEL [Textbook 2nd ed] / 2010, Vukolov E. A., M.: FORUM p. 463.

7. Gruber J. Ekonometriya /1998, Gruber J. vol(2), K: Nichlava, p. 384. (in Ukrainian)

8. Klimenko M.O. Osnovy ta metodolohiya naukovykh doslidzhen [Textbook] / 2010, Klimenko M.O., Feshchenko V.P., Voznyuk N.M.K: Agrarian education, p. 351. (in Ukrainian) Ukrainian)

9. Korolev O.A. Econometrics: [Textbook 2nd ed] / 2005, Korolev O.A., K.: Knyha, p.416. (in

10. Modeli i metody sotsialno-ekonomichnoho prohnozuvannya [Textbook] / 2005, [V. M. Geets and others]. H.: INZHEK, p. 396. (in Ukrainian)

11. Nelep V.M. Planuvannya na ahrarnomu pidpryyemstvi: [Textbook 2nd ed.] / Nelep V.M / KNEU, 2004, p. 495. (in Ukrainian)

12. Organization of agrarian economy management [Monograph] / [M. F. Kropyvko, V.P. Nemchuk, V.V. Rossokha and others]; for order. M.F. Kropivko / 2008, K.: NSC IAE, p. 420. (in Ukrainian) 